Hana BĚLÍKOVÁ ${ }^{1 *}$, Martin MÉSZÁROS ${ }^{2}$, Ladislav VARGA ${ }^{3}$, Július ÁRVAY ${ }^{4}$ Barbara WIŚNIOWSKA-KIELIAN ${ }^{5}$, Krzysztof GONDEK ${ }^{5}$, Jacek ANTONKIEWICZ ${ }^{5}$ Stanislav TORMA ${ }^{6}$, Boris LAZAREVIĆ ${ }^{7}$, Eduardo von BENNEWITZ ${ }^{8}$ and Tomáš LOŠÁK ${ }^{9}$

\title{
THE EFFECT OF DIFFERENT FORMS OF SULPHUR ON INCIDENCE OF APPLE SCAB ON APPLE TREE (Malus $x$ domestica BORKH) GLOSTER CV.
}

\author{
WPŁYW RÓŻNYCH FORM SIARKI NA WYSTĘPOWANIE PARCHA \\ JABLONIOWEGO NA JABLONIACH \\ (Malus $x$ domestica BORKH) ODMIANY GLOSTER
}

\begin{abstract}
From 2014 to 2015 the influence of foliar application of sulphur on apple trees (Gloster cv.)was investigated in the apple orchard at the Research and Breeding Institute of Pomology in Holovousy (North-East Bohemia, Czech Republic). The experiment was based on foliar applications of fertilizers containing different forms of sulphur: elemental $\mathrm{S}^{0}$, sulphate $\mathrm{SO}_{4}{ }^{2-}$ and thiosulphate $\mathrm{S}_{2} \mathrm{O}_{3}{ }^{2-}$ (in combination with other macro- and microelements) and fungicides with or without sulphur: Kumulus $\left(\mathrm{S}^{0}+\mathrm{F}\right)$ and the conventional fungicide programme $(\mathrm{F})$, in the respective treatments. Apple scab incidence on leaves and fruits was investigated in each experimental year according to the relevant methodology of the OEPP/EPPO standard PP1/5(3) Venturia inaequalis. Data on the incidence of apple scab correlate with the process of pathogen life cycle and risk of infection on the given dates. The incidence of apple scab was the lowest in 2014 in treatment $\mathrm{S}^{0}+\mathrm{F}(10.8 \%$ on leaves, $2.8 \%$ on fruits) and $\mathrm{F}(15.8 \%$ on leaves, $6 \%$ on fruits) where conventional fungicides were used. When compared with the other treatments these treatments were the most effective even if the incidence of scab in the
\end{abstract}

\footnotetext{
${ }^{1}$ Faculty of AgriSciences, Mendel University in Brno, Zemědělská 1, 61300 Brno, Czech Republic

${ }^{2}$ Research and Breeding Institute of Pomology Holovousy Ltd., Holovousy 129, 50801 Hořice, Czech Republic,phone +420 491848226, email: Meszaros@ vsuo.cz

${ }^{3}$ Department of Agrochemistry and Plant Nutrition, Slovak University of Agriculture in Nitra, Tr. A. Hlinku 2, 94976 Nitra, Slovakia, email: ladislav.varga@uniag.sk

${ }^{4}$ Department of Chemistry, Slovak University of Agriculture in Nitra, Tr. A. Hlinku 2, 94976 Nitra, Slovakia, email: julius.arvay@uniag.sk

${ }^{5}$ Department of Agricultural and Environmental Chemistry, University of Agriculture in Krakow, al. A. Mickiewicza 21, 31-120 Kraków, Poland, email: rrkielia@cyf-kr.edu.pl, rrgondek@cyf-kr.edu.pl, rrantonk@cyf-kr.edu.pl

${ }^{6}$ National Agricultural and Food Centre, Soil Science and Conservation Research Institute, regional work place Prešov, Raymannova 1, 08001 Prešov, Slovak Republic, email: s.torma@vupop.sk

${ }^{7}$ Department of Plant Nutrition, University of Zagreb, Svetošimunskacesta 25, 10000 Zagreb, Croatia, email: blazarevic@agr.hr

${ }^{8}$ Institute of Plant Production and Protection, Universidad Austral de Chile, Campus Isla Teja, Isla Teja s/n. Valdivia, Chile, email: evba70@gmail.com

${ }^{9}$ Faculty of Regional Development and International Studies, Mendel University in Brno, Zemědělská 1, 61300 Brno, Czech Republic, email: tomas.losak@mendelu.cz

*Corresponding author: Belikova@vsuo.cz
} 
individual treatments in 2015 increased by 28 to $60 \%$ due to high infection pressure. The results confirmed the efficiency of the conventional fungicide programme $\left(S^{0}+F\right.$ and $\left.F\right)$ against apple scab incidence on fruits. What is more, the results were slightly better in the treatment, where the conventional fungicide programme was combined with fertilizer containing elemental $S\left(S^{0}+F\right)$ in comparison with fungicides applied alone $(F)$. The effect of the other forms of sulphur $\left(\mathrm{SO}_{4}\right.$ and $\left.\mathrm{S}_{2} \mathrm{O}_{3}\right)$ on apple scab control has not been confirmed. According to the results, the application of the conventional fungicide programme $\left(\mathrm{S}^{0}+\mathrm{F}\right.$ and $\left.\mathrm{F}\right)$ is more effective against scab incidence than the inorganic forms of sulphur alone.

Keywords: foliar fertilization, fungicide, apple orchards, Venturia inaequalis

\section{Introduction}

The apple scab disease is the most widespread apple tree disease of fruit growing in the Czech Republic with severe economic consequences. Fruits damaged by the apple scab disease induce serious losses in apple production. These fruits cannot be sold in high-quality grades, furthermore, these fruits are much more susceptible to rotting during storage [1].

The incidence of apple scab depends on many factors, the most important of which are the source of pathogen infection from the previous growing season, weather conditions and the susceptibility of the variety to the pathogen. A possible way of control of the apple scab disease is to apply effective fungicides in recommended practices which is considerably difficult in organic production. The next effective way of controlling apple scab in apple orchards is the application of lime sulphur in combination with other fungicides containing sulphur and copper [2]. Approximately $70 \%$ of all the applied fungicides in integrated production (from 15 to 20 fungicide applications per year) are used to control the apple scab disease [2]. Many of them are prohibited in organic farming, therefore, they must be replaced with authorized fungicides, adjuvants or fertilizers intended for organic production. Among the inorganic compounds tested for the control of the apple scab disease in organic apple production were sulphur or copper [3-5].

The apple scab disease is caused by the fungus Venturia inaequalis (Cooke) G. Wint. The life cycle of Venturia is by both sexual (formed by ascospores) and asexual (formed by conidia) reproduction. The main source of primary infection in the orchard are ascospores. The ascospores are ejected from mature pseudothecia which overwinter in the infected leaves from the previous growing season [6]. Thus, the amount of pseudothecia is closely related to the amount of fallen leaves from the previous year. Another source of infection are conidia which can overwinter in apple tree wood and buds [7, 8].

In addition to the fungicide effect of sulphur, the primary function of sulphur in the plant is very often overlooked. Sulphur is an element essential for plant growth and development. It is the building block for the synthesis of amino acids (cysteine, methionine), proteins, coenzymes, sulpholipids and polysaccharides. The plant requires 0.1 to $0.5 \%$ of sulphur in dry weight for its optimal growth $[9,10]$. The total sulphur content in soil varies from 0.01 to $0.1 \%$ or 50 to $500 \mathrm{mg} \cdot \mathrm{kg}^{-1}$; and the commonly given rate is about $260 \mathrm{mg} \mathrm{S} \cdot \mathrm{kg}^{-1}[11,12]$. According to research, the total content of sulphur in soils of the Czech Republic has decreased from $221 \mathrm{mg} \mathrm{S} \cdot \mathrm{kg}^{-1}$ (data of 1981) to $204 \mathrm{mg} \mathrm{S} \cdot \mathrm{kg}^{-1}$ (data of 2007) [13]. The high-yielding apple tree (14 years old, Golden Delicious cv.) takes up $15.4 \mathrm{~kg} \mathrm{~S} \cdot \mathrm{ha}^{-1}$ for the production of $90 \mathrm{Mg}$ of fruit $\cdot \mathrm{ha}^{-1}$ [14].

The main sources of sulphur in the soil are: bedrock, organic matter, sulphur gases in the atmosphere, precipitation, fungicides and fertilizers [10, 15]. In the 1980's and 1990's 
the amount of sulphur from anthropogenic activities was very high and environmentally-unfriendly in the Czech Republic. The dry and wet depositions of sulphur (resulting mainly from combustion of fuels) were more than $100 \mathrm{~kg} \cdot \mathrm{ha}^{-1}$ in 1991 [13]. In relation to strictly limited $\mathrm{SO}_{2}$ emissions since 1989 , the emission of sulphur has dramatically fallen in the past 40 years in the Czech Republic. It has decreased by $88 \%$ (to $217 \mathrm{Gg} \cdot \mathrm{yr}^{-1}$ since 1990 to 2007[16]. Research focused on sulphur showed that $60-78 \%$ of the total sulphur uptake by winter wheat came from atmospheric deposition [17]. In the 1980 's no attention was devoted to sulphur fertilization of crops. The total consumption of phosphorous and potassium mineral fertilizers, containing sulphur as a side-element, has gradually declined. Some other sulphur-containing fertilizers (e.g. single superphosphate SSP) were replaced by new low-S-containing or S-free fertilizers (monoammonium phosphate) $[18,19]$. Similarly to mineral $\mathrm{P}$ and $\mathrm{K}$ fertilizers, the source of sulphur from organic fertilizers has also decreased. According to some studies, the annual rate of $10 \mathrm{Mg} \cdot \mathrm{ha}^{-1}$ of manure supplied the soil with $8 \mathrm{~kg} \mathrm{~S} \cdot \mathrm{ha}^{-1}$ [13]; however after 1970 the application of manure declined due to the decreasing livestock numbers (the cattle population decreased by $55.1 \%$, pig population decreased by $34.8 \%$ ) [20]. Furthermore, some fungicides containing sulphur as an active substance were replaced by some other active substance with a systemic effect.

Due to these changes, sulphur inputs into conventional fruit orchards have been decreasing in recent decades and sulphur deficiency in plant nutrition is becoming a current problem not only in the Czech Republic but throughout Europe [13, 17, 21].

The objective of the study was to compare the effectiveness of sulphur foliar fertilizers (containing different forms of sulphur) and fungicides (either permitted or prohibited for organic farming) against the incidence of apple scab.

\section{Material and methods}

A two-year trial (2014-2015) was established on $4^{\text {th }}$ April 2014 at the Research and Breeding Institute of Pomology in Holovousy (North-East Bohemia, Czech Republic). The experiment was set up in an apple orchard with the 'Gloster' variety with a high apple scab susceptibility, grafted onto M9 rootstock. The trees are planted in a central leader with spacing $1.8 \times 4.5$ meters. The orchard is situated at an altitude of $287 \mathrm{~m}$ (above sea level). Calcium ammonium nitrate $(\mathrm{CAN})$ at a rate of $50 \mathrm{~kg} \mathrm{~N} \cdot \mathrm{ha}^{-1}$ was applied to stimulate growth of the trees at the beginning of each experimental year. Agrochemical characteristics of the soil of the experimental orchard prior to trial establishment in 2013 are shown in Table 1.

Table 1

Agrochemical characteristics of soil prior to trial establishment (Mehlich III)

\begin{tabular}{|c|c|c|c|c|c|}
\hline \multirow{2}{*}{$\mathbf{p H} / \mathbf{C a C l}_{\mathbf{2}}$} & $\mathbf{P}$ & $\mathbf{K}$ & $\mathbf{M g}$ & $\mathbf{C a}$ & $\mathbf{S}^{*}$ \\
\cline { 2 - 6 } & \multicolumn{4}{|c|}{$\left[\mathbf{m g} \cdot \mathbf{k g}^{-\mathbf{1}}\right]$} \\
\hline 7.19 & 78 & 197 & 133 & 3,632 & 4.47 \\
\hline neutral & suitable & suitable & suitable & high & low \\
\hline
\end{tabular}

* water-extractable sulphur

The experiment was based on foliar application of fertilizers containing different forms of sulphur: elemental, sulphate and thiosulphate (in combination with other macro- and 
microelements) and fungicides with or without sulphur. The experiment involved six treatments, as shown in Table 2. Each of these treatments had four repetitions.

Table 2

Treatments used in the experiment

\begin{tabular}{|c|c|c|c|c|}
\hline $\begin{array}{c}\text { Treatment } \\
\text { No. }\end{array}$ & Acronym & Description & $\begin{array}{c}\text { Rate of sulphur } \\
{\left[\mathbf{k g} \cdot \mathbf{h a}^{-1} \mathbf{]}\right.}\end{array}$ & $\begin{array}{c}\text { Fertilizer and/or fungicide } \\
\text { (content of S) }\end{array}$ \\
\hline 1 & Control & Untreated control & 0 & - \\
\hline 2 & $\mathrm{~S}^{0}$ & Elemental sulphur & 3.2 & Sulfika SB-C $^{\mathrm{a}}(35 \%)$ \\
\hline 3 & $\mathrm{SO}_{4}{ }^{2-}$ & Sulphates & 3.2 & $\mathrm{EPSO} \mathrm{Top}^{\mathrm{b}}(13 \%)$ \\
\hline 4 & $\mathrm{~S}_{2} \mathrm{O}_{3}{ }^{2-}$ & Thiosulphates & 3.2 & $\mathrm{SK} \mathrm{sol}^{\mathrm{c}}(17 \%)$ \\
\hline 5 & $\mathrm{~S}^{0}+\mathrm{F}$ & $\begin{array}{c}\text { Elemental sulphur } \\
\text { + fungicides without sulphur }\end{array}$ & 3.2 & $\begin{array}{c}\text { Sulfika SB-C }(35 \%), \\
\text { standard fungicides }\end{array}$ \\
\hline 6 & $\mathrm{~F}$ & $\begin{array}{c}\text { Fungicide containing sulphur } \\
\text { + fungicides without sulphur }\end{array}$ & 3.2 & $\begin{array}{c}\text { Kumulus } \\
\text { fungicides }\end{array}$ \\
\hline
\end{tabular}

The exact composition of applied fertilizers and fungicide: ${ }^{a}$ elemental sulphur $35 \%$, boron $5 \%$, carbon $2.5 \%$; b sulphate sulphur $33 \%$, magnesium $9 \%$; ${ }^{\text {c }}$ thiosulphate sulphur $17 \%$, potassium $21.6 \%$; ${ }^{\mathrm{d}}$ elemental sulphur $80 \%$

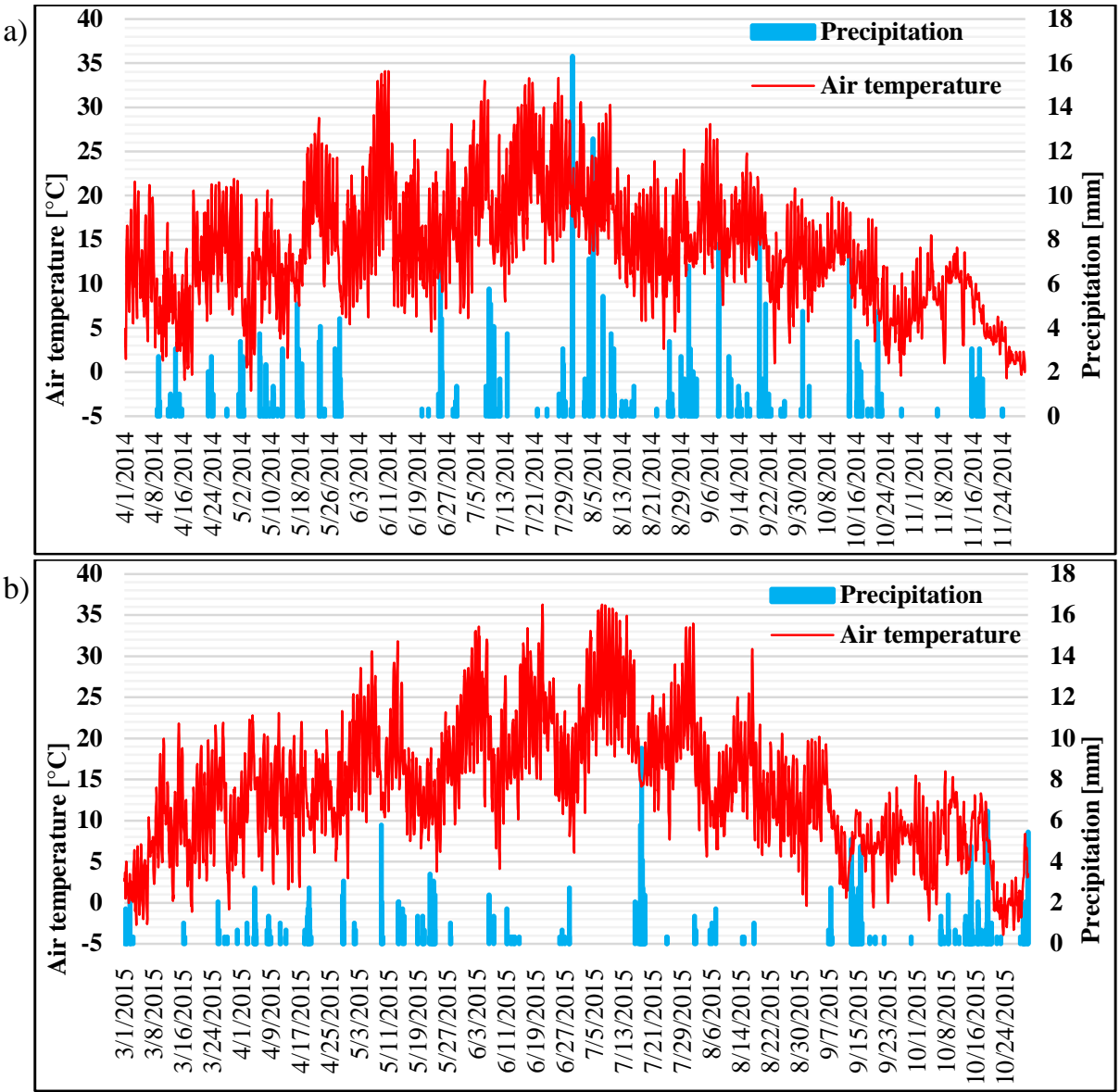

Fig. 1. Meteorological data from the weather station on the experimental plot in: a) 2014 and b) 2015 
No fungicides were applied in treatments 1 to 4 . Foliar fertilizer containing elemental sulphur in combination with a conventional fungicide programme (without sulphur) was applied in treatment no 5. The fungicide Kumulus (containing $80 \%$ of elemental sulphur) followed by the conventional fungicide programme (without sulphur) were applied during the growing season in treatment no 6. Active substances applied within the conventional fungicide programme (treatments 5 and 6) were as follows: myclobutanil $20 \%$, dodine $40 \%$, copper hydroxide $77 \%$, pyrimethanil $30 \%$, cyprodinil $50 \%$, fluquinconazole $5 \%$. The same rate of sulphur, i.e. $3.2 \mathrm{~kg} \mathrm{~S} \cdot \mathrm{ha}^{-1}$ per growing season, was applied in each treatment (except the first - untreated control). This amount of sulphur was split up into 8 application dates during the growing season (6 ${ }^{\text {th }}$ May 2014-18 ${ }^{\text {th }}$ August 2014 and $22^{\text {nd }}$ May 2015-31 $1^{\text {st }}$ August 2015). Foliar applications were carried out in two-week intervals.

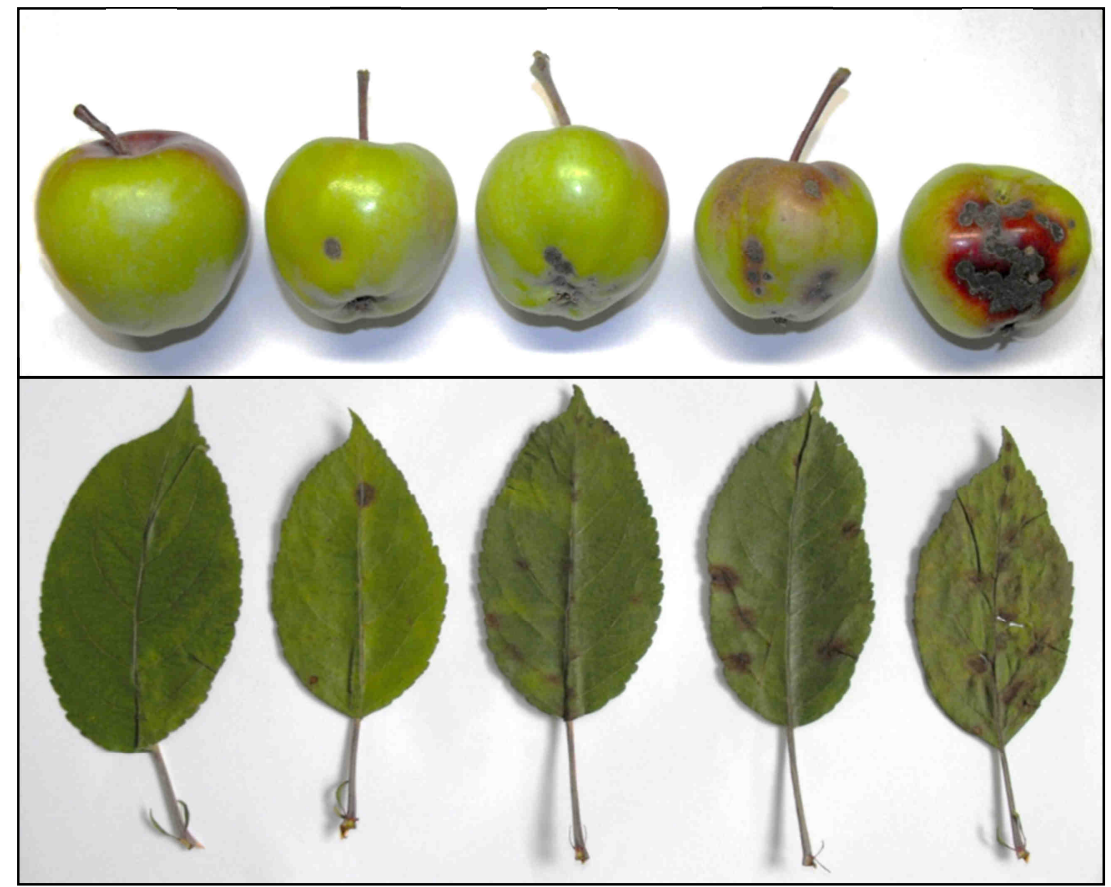

\begin{tabular}{|c|l|}
\hline Value & Degree of apple scab incidence \\
\hline $\mathbf{1}$ & any scab lesions \\
\hline $\mathbf{2}$ & lesions on an area of less than $\mathbf{0 . 2 5} \mathbf{c m}^{2}$ of leaf/fruit area \\
\hline $\mathbf{3}$ & lesions on an area of $\mathbf{0 . 2 5}$ to $\mathbf{1} \mathbf{~ c m}^{2}$ of leaf/fruit area \\
\hline $\mathbf{4}$ & lesions on an area of $\mathbf{1}$ to $\mathbf{4} \mathbf{~ c m}^{2}$ of leaf/fruit area \\
\hline $\mathbf{5}$ & lesions on an area of over $\mathbf{4} \mathbf{c m}^{2}$ of leaf/fruit area \\
\hline
\end{tabular}

Fig. 2. Scale for assessment of apple scab incidence on leaves and fruits

The fruits were harvested at full maturity on the $8^{\text {th }}-9^{\text {th }}$ October 2014 and the $5^{\text {th }}-6^{\text {th }}$ November 2015. Plant growth and development (tree budding, fruit ripening etc.) were 
delayed because of colder weather conditions in spring; that was why the dates of application and fruit harvest were deferred in the second experimental year 2015 (Fig. 1).

Several assessments of apple scab incidence were investigated in each experimental year: scab incidence corresponding to the primary infection on leaves and fruits (from the end of June to mid-July), scab incidence corresponding to the secondary infection of leaves (from the beginning to the end of September) and scab incidence on fruits at harvest time. Apple scab incidence was investigated in accordance with the relevant methodology of the EPPO standard PP1/5 (3) Venturia inaequalis [22]. Scab incidence was assessed on 100 leaves and 50 fruits per repetition (400 leaves and 200 fruits per treatment). The degree of apple scab incidence on leaves and fruits was assessed on a 1 to 5 scale. The value indicates the scab lesions per leaf or fruit area (Fig. 2).

All results were statistically evaluated using the single factor ANOVA and subsequent analysis with Tukey HSD test.

\section{Results and discussion}

The obtained results confirmed the strong weather-dependence of the apple scab incidence in the respective year. Infection pressure is high in warm and wet weather conditions (temperature above $0{ }^{\circ} \mathrm{C}$ during the leaf wetness period) which allows spore germination on the leaf surface and faster spreading of the pathogen [7]. Figure 1 shows the weather conditions from both experimental years (2014 and 2015).

The effectiveness of some inorganic compounds (especially sulphur or copper) against apple scab incidence was investigated in several studies [2-5]. Sulphur applications against apple scab have proved the importance of the sulphur form, its rate and application timing (phenological stage, environmental condition). A small amount of sulphur applied against apple scab infection may not be effective, especially in cold weather $[3,23,24]$. On the contrary, re-application of a large amount of sulphur may cause a phytotoxic side-effect [2].

The evaluated data of apple scab incidence correlate with the process of pathogen infection on the given dates. Our results on the evaluation of apple scab incidence showed significant differences between data collected at the time of primary infection (June or July) and data from secondary infection (September or October) in the first experimental year (2014). While significant differences between primary and secondary infection were recorded in 2014, no significant differences were found out between primary and secondary infection in the second experimental year (2015). A detailed comparison of all six treatments showed that scab incidence was the lowest on leaves in treatment $\mathrm{S}^{0}+\mathrm{F}$ $(10.8 \%)$ and slightly higher in treatment $\mathrm{F}(15.8 \%)$ as compared to the other four treatments: control $(51.8 \%), \mathrm{S}^{0}(51.8 \%), \mathrm{SO}_{4}(56.3 \%)$ and $\mathrm{S}_{2} \mathrm{O}_{3}(53.5 \%)$ in June 2014 (Fig. 3). On account of the high infection pressure of the pathogen in the period from June to September 2014, the incidence of scab on leaves increased by 28-64\% (in the individual treatments). In September 2014 the lowest incidence of scab was also detected in treatments $\mathrm{S}^{0}+\mathrm{F}(74.5 \%)$ and $\mathrm{F}(68.5 \%)$, but the differences among the six treatments were not significant. On the contrary, the incidence of apple scab on leaves was the highest in the $\mathrm{S}^{0}$ treatment $(92.5 \%)$ in October 2015 , although this data was not statistically significant in comparison with the control treatments, $\mathrm{SO}_{4}$ and $\mathrm{S}_{2} \mathrm{O}_{3}$, but it was significantly higher than treatments $\mathrm{S}^{0}+\mathrm{F}$ and $\mathrm{F}$. 


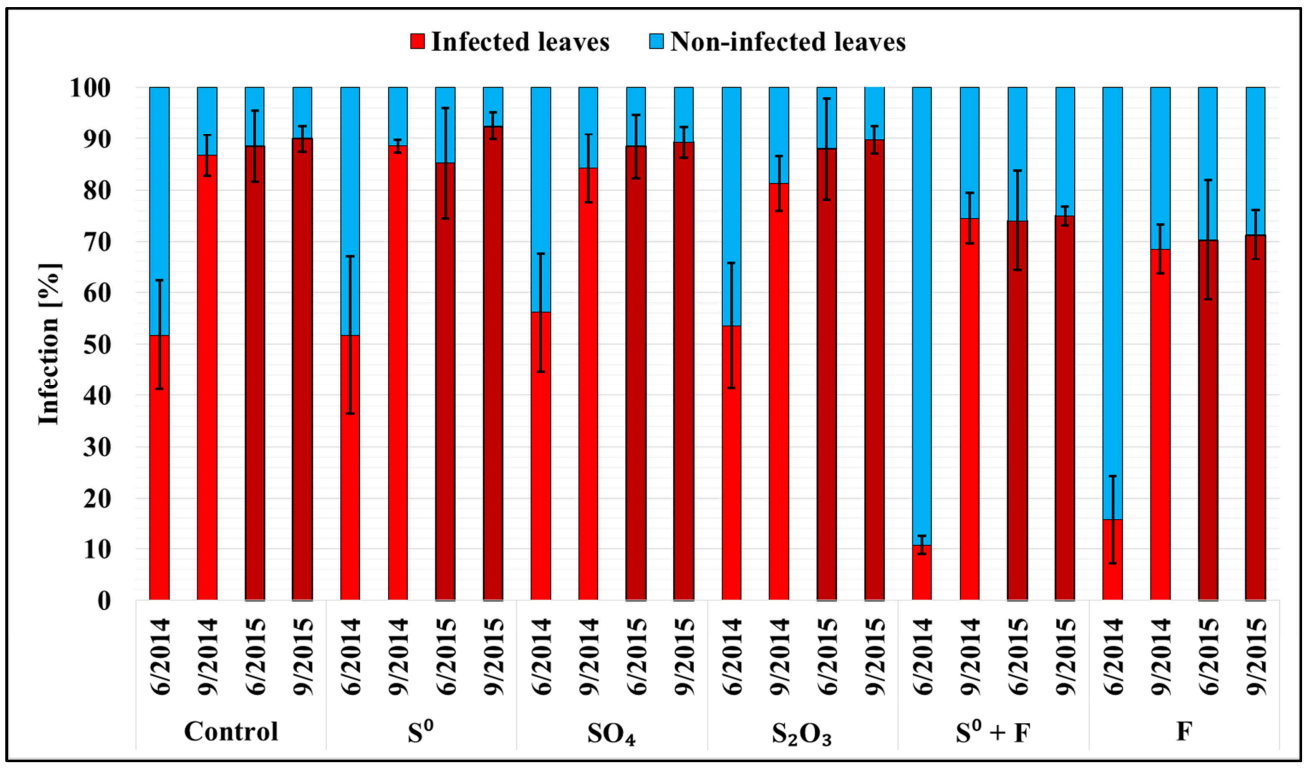

Fig. 3. Apple scab incidence on leaves in 2014 and 2015. Treatments: $S^{0}$ - elemental sulphur (Sulfika $\mathrm{SB}-\mathrm{C}$ ), $\mathrm{SO}_{4}$ - sulphates (EPSO Top), $\mathrm{S}_{2} \mathrm{O}_{3}$ - thiosulphates (SK Sol), $\mathrm{S}^{0}+\mathrm{F}$ - elemental sulphur + fungicides without sulphur, $\mathrm{F}$ - fungicide containing elemental sulphur + fungicides without sulphur

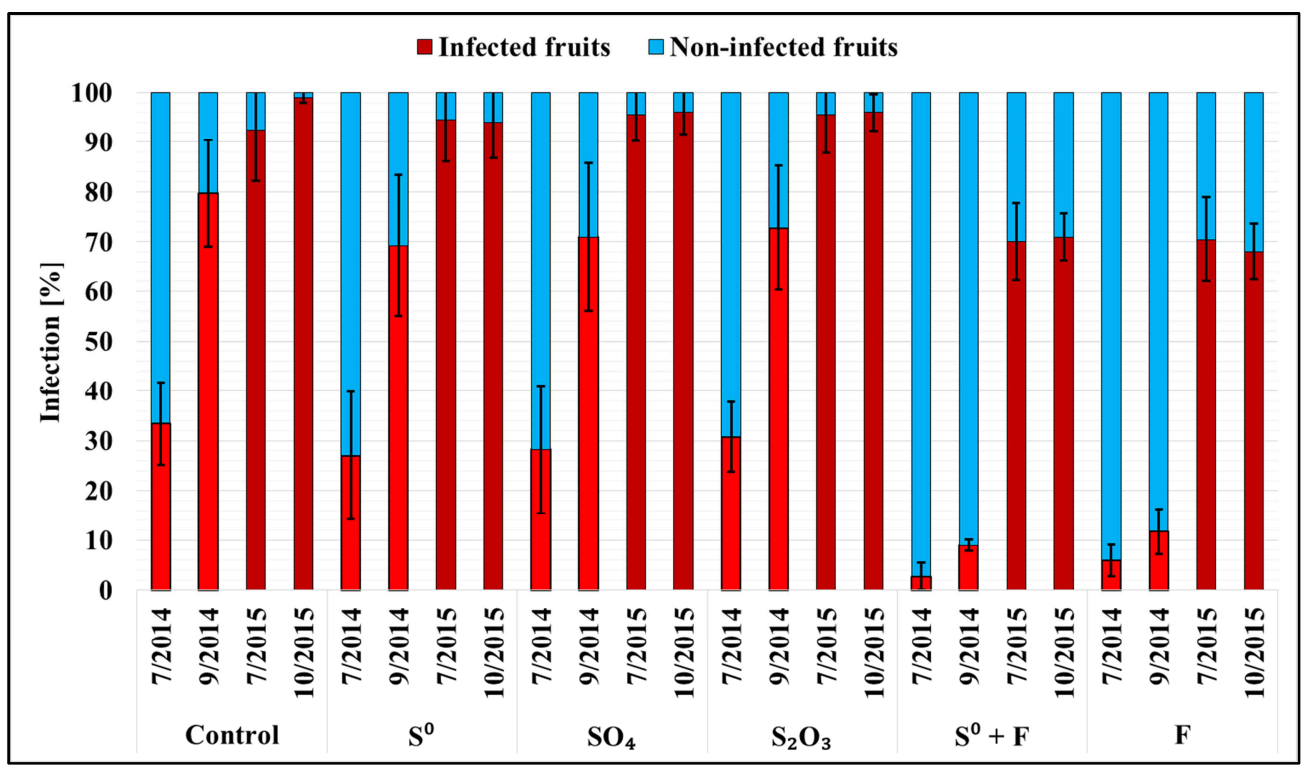

Fig. 4. Apple scab incidence on fruits in 2014 and 2015. Treatments: $\mathrm{S}^{0}$ - elemental sulphur (Sulfika $\mathrm{SB}-\mathrm{C}$ ), $\mathrm{SO}_{4}$ - sulphates (EPSO Top), $\mathrm{S}_{2} \mathrm{O}_{3}$ - thiosulphates (SK Sol), $\mathrm{S}^{0}+\mathrm{F}$ - elemental sulphur + fungicides without sulphur, $\mathrm{F}$ - fungicide containing elemental sulphur + fungicides without sulphur 
Scab incidence on fruits correlates with scab incidence on leaves, which was the lowest in treatments $\mathrm{S}^{0}+\mathrm{F}(2.8 \%)$ and $\mathrm{F}(6 \%)$ as compared to the other treatments: control $(33.5 \%), \mathrm{S}^{0}(27 \%), \mathrm{SO}_{4}(28.3 \%)$ and $\mathrm{S}_{2} \mathrm{O}_{3}(30.8 \%)$ in July 2014. The incidence of scab on fruits increased by $6-46 \%\left(\mathrm{~S}^{0}+\mathrm{F}\right.$ and control treatment, respectively) in the period from June to September 2014 (Fig. 4).

In September 2014 the incidence of scab on fruits was the lowest in treatments $\mathrm{S}^{0}+\mathrm{F}$ $(9 \%)$ and $\mathrm{F}(11.8 \%)$; in the other four treatments it was significantly higher: control $(79.8 \%), \mathrm{S}^{0}(69.3 \%), \mathrm{SO}_{4}(71 \%)$ and $\mathrm{S}_{2} \mathrm{O}_{3}(72.8 \%)$. The incidence of apple scab on fruits was the highest in the control treatment $(99 \%)$ in October 2015 and was significantly higher than in treatments $\mathrm{S}^{0}+\mathrm{F}$ and $\mathrm{F}$.

According to the results of both experimental years, the damage to fruit production in all treatments was 5-8 times more severe in 2015 than in 2014. A gradual and fast spread of the pathogen infection was observed during the two years of the experiment (Figs. 3 and 4). If the protection strategy against primary infection is not effective enough, the source of infection can overwinter in the orchard (pseudothecia in leaves on the ground). In such a case the pathogen infection of the apple scab disease is much higher and losses caused by apple scab increase in the next growing season [25]. These facts confirm the conclusions of previous researches - that apple production is not economic and feasible under conditions of the temperate zone if products with a fungicide effect are not applied [26-28].

The results indicate that treatments $S^{0}+F$ and $F$ (with the conventional fungicide programme) are more effective against apple scab than treatments with inorganic sulphur, in accordance with the findings of Ellis et al. [27]. In our treatments $S^{0}+F$ and $F$ the losses in fruit production were almost by $70 \%$ lower in 2014 and by $30 \%$ lower in 2015 than in the other treatments. These results confirmed the effectiveness of the conventional fungicide programme against apple scab on fruits. The effect of elemental sulphur or other forms $\left(\mathrm{SO}_{4}\right.$ and $\left.\mathrm{S}_{2} \mathrm{O}_{3}\right)$ has not been confirmed. The re-applied $0.5 \%$ elemental sulphur in 5-7-day intervals is effective at a low infection pressure but it is not effective at a high infection pressure [29]. A combination of elemental and other forms of sulphur provides better apple scab control. The foliar application of $0.2-0.5 \%$ elemental sulphur supplemented with $2.0 \%$ lime sulphur is more effective against the apple scab disease than elemental sulphur alone [29]. One of the curative formulations effective against apple scab disease is a combination of calcium polysulphide and calcium thiosulfate. This treatment is effective when applied within 30-72 hours after inoculation of Venturia sp. On the other hand, the effect of elemental sulphur is less phytotoxic than a combination of different forms of sulphur or conventional fungicides [4, 23, 30].

The main fungicide activity of elemental sulphur is on the plant surface. On this basis, the effect of elemental sulphur is non-systemic, preventive and its repeated applications are needed if protection is to be effective $[31,32]$. The fungicides containing this form of sulphur are usually used as contact-protectant fungicides applied before and during the infection time (30-72 hours within inoculation of Venturia by ascospores) [23, 33]. Because of the principles of fungicide action-the treatments in the experiment are different in their systemic and non-systemic fungicide effect. Some active substances (myclobutanil, dodine, cyprodinil, fluquinconazole) used within the conventional fungicide programme $\left(\mathrm{S}^{0}+\mathrm{F}\right.$ and F) have a systemic fungicide effect in contrast to the non-systemic effect of elemental sulphur $\left(\mathrm{S}^{0}\right)$. This non-systemic effect in the treatment is less effective throughout the long period of a high infection pressure. 


\section{Conclusions}

The incidence and development of scab disease in the apple orchard is strongly weather-dependent. Our results correlate with the process of pathogen infection (Venturia inaequalis). The data collected within primary infection were significantly lower than in secondary infection, when the infection pressure was much higher. The results showed a fast spread of the pathogen infection during the experimental years 2014-2015. For this reason it is very important to choose effective control of apple scab in the orchard, especially during primary infection. If the protection strategy against scab is not effective, the source can overwinter in the orchard and increase losses in fruit production in the next growing season.

The results of this study confirmed the effectiveness of the conventional fungicide programme $\left(S^{0}+F\right.$ and $\left.F\right)$ against apple scab incidence on fruits. In addition, apple scab incidence was slightly lower in the treatment, where the conventional fungicide programme was combined with a fertilizer containing elemental $S\left(S^{0}+F\right)$ in comparison with fungicides applied alone $(\mathrm{F})$. The effect of elemental sulphur alone or of other forms of sulphur has not been confirmed. However, sulphur is one of the most active agents used against apple scab disease in organic production. The sulphur fungicide activity is mainly non-systemic, therefore, it is recommended to apply sulphur several times as a protectant fungicide during the time of primary infection (within 30-72 hours of pathogen inoculation). Further research is needed to clarify the efficiency of elemental forms of sulphur in combination with fungicides against apple scab incidence.

\section{Acknowledgements}

This research was funded by the projects CZ.1.05/2.1.00/03.0116 - Pomology Research Institute within the Operation Programme Research and Development for Innovations and LO 1608 - Pomology Research Centre within the National Sustainable Development Strategy.

\section{References}

[1] OEPP/EPPO. EPPO standards PP 2/18(1), Guidelines on good plant protection practice. Pome fruits. Bulletin OEPP/EPPO Bulletin. 2004;29:379-406. DOI: 10.1111/j.1365-2338.2004.00704.x.

[2] Jamar L, Cavelier M, Lateur M. Biotechnol Agron Soc Environ. 2010;14(3):423-439.DOI: 10.1007/s10658-008-9315-0.

[3] Holb IJ, Schnabel G. Australas Plant Pathol. 2008;37(5):454-459. DOI: 10.1071/AP08041.

[4] Jamar I, Lefrancq B, Fassotte C, Lateur M. Eur J Plant Pathol. 2008;122(4):481-493. DOI: 10.1071/AP08041.

[5] Profaizer D, Baldessari M, Giuliani G, Angeli G. IOBC-WPRS Bulletin. 2013;91:73-79. https://www.iobc-wprs.org/members/shop_en.cfm?mod_Shop_detail_produkte $=19$.

[6] Rossi V, Giosuè S, Bugiani R. Bulletin OEPP/EPPO Bulletin. 2003;33(3):407-414. DOI: 10.1111/j.1365-2338.2003.00665.x.

[7] Carisse O, Tremblay D-M, Jobin T, Walker AS. Disease decision support systems: their impact on disease management and durability of fungicide effectiveness. In: Carisse O, editor. Fungicides, $1^{\text {st }}$ ed. Rijeka: InTech; 2010;177-200. DOI: 10.5772/13335.

[8] González-Domínguez E, Armengol J, Rossi V. Front Plant Sci. 2017;8:1-19. DOI: 10.3389/fpls.2017.01496.

[9] Hawkesford M, Horst W, Kichey T, Lambers H, Schjoerring J, Skrumsager Møller I, White P. Functions of macronutrients. In: Marchner P, editor. Marchner's Mineral Nutrition of Higher Plants, $3^{\text {rd }}$ ed. London: Academic Press; 2012;135-189. DOI:10.1016/B978-0-12-384905-2.00006-6.

[10] Saha B, Saha S, Roy PD, Padhan D, Pati S, Hazra GC. Microbial transformation of sulfur: an approach to combat the sulphur deficiencies in agricultural soils. In: Meena VS, editor. Role of Rhizospheric Microbes in 
Soil: Volume 2: Nutrient Management and Crop Improvement, $1^{\text {st }}$ ed. Singapore: Springer Nature; 2018;77-97. DOI: 10.1007/978-981-13-0044-8.

[11] Sager M. Agriculture. 2012;2(1):1-11. DOI: 10.3390/agriculture2010001.

[12] Haneklaus S, Bloem B, Schnug E, De Kok LJ, Stulen I. Sulfur. In: Barker AV, Pilbeam DJ, editors. Handbook of Plant Nutrition. New York: Taylor and Francis Group; 2007;183-238. ISBN: 978082475904-9.

[13] Balík J, Kulhánek M, Černý J, Száková J, Pavlíková D, Čermák P. Plant Soil Environ. 2009;55(8):344-352. DOI:10.17221/101/2009-PSE.

[14] Neilsen GH, Neilsen D. Nutritional Requirements of Apple. In: Ferree DC, Warrington IJ, editors. Apples: Botany, Production and Uses, $1^{\text {st }}$ ed. Oxon: CAB International; 2003;12:267-302. DOI:10.1079/9780851995922.0267.

[15] Prasad R, Shivay YS. Sulfur in soil, plant and human nutrition. Proc National Acad Sci, India Sect B Biol Sci. 2018;88(2):429-434. DOI: 10.1007/s40011-016-0769-0.

[16] Oulehle F, Kopáček J, Chuman T, Černohous V, Hůnová I, Hruška J, et al. Atmos Environ. 2016;140:456-468. DOI: 10.1016/j.atmosenv.2016.06.028.

[17] Zhao FJ, Knights JS, Hu ZY, McGrath SP. J Environ Qual. 2003;32(1):33-39. DOI: 10.2134/jeq2003.3300.

[18] Dick WA, Kost D, Chen L. Availability of Sulfur to Crops from Soil and Other Sources. In: Jez J, editor. Sulfur: A Missing Link between Soils, Crops, and Nutrition, $1^{\text {st }}$ ed. Washington, USA: American Society of Agronomy; 2008;59-82. DOI: 10.2134/agronmonogr50.c5.

[19] Lucheta AR, Lambais MR. Rev Bras Cienc Solo. 2012;36(5):1369-1379. DOI: 10.1590/S0100-06832012000500001.

[20] Kopáček J, Veselý J. Atmos Environ. 2005;39(12):2179-2188. DOI: 10.1016/j.atmosenv.2005.01.002.

[21] Scherer HW. Eur J Agron. 2001;14(2):81-111. DOI: 10.1016/S1161-0301(00)00082-4.

[22] OEPP/EPPO. EPPO standards PP 1/5(3). Efficacy evaluation of fungicides. Venturia inaequalis and V. Pyrina. Bulletin OEPP/EPPO Bulletin: Paris, France, 1990;20(3):1-18. DOI: 10.1111/j.1365-2338.1990.tb00166.x.

[23] Holb IJ, De Jong PF, Heijne B. Ann Appl Biol. 2003;142(2):225-233. DOI: 10.1111/j.1744-7348.2003.tb00245.x.

[24] Pavlista AD. Agron J. 2005;97(2):599-603. DOI: 10.2134/agronj2005.0599.

[25] Rossi V, Giosuè S, Bugiani R. Bulletin OEPP/EPPO Bulletin. 2007;37(2):300-308. DOI: 10.1111/j.1365-2338.2007.01125.x.

[26] Abott CP, Beckerman JL. Plant Dis. 2018;102(1):231-236. DOI: 10.1094/PDIS-05-17-0629-RE.

[27] Ellis MA, Ferree DC, Funt RC, Madden LV. Plant Dis. 1998;82(4):428-433. DOI: 10.1094/PDIS.1998.82.4.428.

[28] Gianessi LP, Reigner N. The Value of Fungicides in U.S. Crop Production. Washington: Crop Life Foundation; 2005;183. https://croplifefoundation.org/wp-content/uploads/2016/11/fungicide-full-report.pdf.

[29] Holb IJ. Europ J Hort Sci. 2007;72(2):60-65. https://www.pubhort.org/ejhs/2007/file_254544.pdf.

[30] Cromwell ML, Berkett LP, Darby HM. Hort Sci. 2011;46(9):1254-1259. DOI: 10.21273/HORTSCI.46.9.1254.

[31] Holb IJ. Plant Dis. 2016;100(9):1894-1905.DOI: 10.1094/PDIS-12-15-1416-RE.

[32] Williams JS, Cooper RM. Plant Pathol. 2004;53(3):263-279. DOI: 10.1111/j.0032-0862.2004.01010.x.

[33] Jamar L, Song J, Fauche F, Choi J, Lateur M. J Plant Dis Prot. 2017;124:383-391. DOI: 10.1007/s41348-017-0085-9. 